\title{
CRÍTICA A VIOLÊNCIA E EXCLUSÃO
}

\author{
Rosani Úrsula Ketzer Umbach (Org.)
}

A Revista Eletrônica Literatura e Autoritarismo chega a seu número 30 com a edição de julho-dezembro de 2017, compondo-se de artigos variados que, em sua maioria, tratam de questões relacionadas a autoritarismo, violência, preconceito e às consequências desses fenômenos no tecido social como um todo e nos indivíduos em particular.

Assim, a crítica social, entendida no sentido amplo de crítica ao conservadorismo excludente, a práticas sociais opressoras, a costumes arraigados na prepotência e no arbítrio, enfim, a condições degradantes para os seres humanos, é analisada em obras literárias e culturais nas quais essa temática está impregnada.

Ao problematizar esses aspectos em seus textos, os autores que submeteram seus artigos à Revista Eletrônica Literatura e Autoritarismo contribuem para a reflexão sobre problemas sociais e culturais que se voltam contra indivíduos e grupos, afetando sua integridade.

O primeiro artigo desta edição é de autoria de Carla Lavorati e Maristela Scremin Valério, que discutem, na análise do filme O Tambor, como "a representação do grotesco é um mote para a composição de sentidos que interrogam, de modo geral, a violência e a alienação". Discutindo esses elementos, o artigo O grotesco como crítica social ao nazismo no filme O Tambor, de Volker Schlöndorff mostra como o "microcosmo da vida familiar de Oskar e também a comunidade de Danzig podem ser incorporados à problemática maior: a história da ascensão e queda do nazismo".

O cárcere e a homossexualidade nos campos de concentração e extermínio são tema do artigo Homossexualidade, testemunho e cárcere: pensar o eu, pensar o outro, de autoria de Guido Vieira Arosa e João Camillo Penna, que analisam o posicionamento dos escritores de "dois livros canônicos da literatura de testemunho dos sobreviventes da Segunda Guerra”, Primo Levi e Robert Antelme, em comparação com os testemunhos Antes que anoiteça, do escritor cubano Reinaldo Arenas, e Eu, Pierre Seel, deportado homossexual, do francês Pierre Seel, "ambos enviados a presídio e campo de concentração-extermínio". O texto analisa, então, "as diferentes abordagens do outro e do eu".

Saindo do contexto histórico europeu, incursionando pelo cubano, e passando para o africano, a revista apresenta o artigo intitulado A deformação do sujeito no romance Sozaboy, de Ken Saro-Wiwa, de autoria de André Cechinel e Michelle Maria Stakonski Cechinel. Ao contrário do que diz a crítica, de que se trataria de um romance de formação, os articulistas defendem que Sozaboy, do escritor e ativista político e ambiental nigeriano Ken Saro-Wiwa, descreve "um processo deformativo singular, que, como tal, pede do leitor uma outra epistemologia, uma epistemologia negativa da destruição do sujeito".

O artigo seguinte aborda o contexto histórico latino-americano. Em Reforma agrária e identidade nacional no conto "Nos han dado la tierra", de Juan Rulfo: uma crítica social, 
Ana Paula Cantarelli analisa o processo de reforma agrária representado no conto do escritor mexicano, destacando a "crítica à distribuição de terras inférteis por parte do governo que, ao invés de atenuar as desigualdades sociais, acaba por perpetuá-las e, em alguns casos, por extremá-las”. Além disso, a autora discute a questão da identidade nacional associada à posse da terra.

O artigo de Alceni Elias Langner e Gilmei Francisco Fleck, intitulado A violênca de Lope de Aguirre nas crônicas do descobrimento e a sua releitura no romance histórico latino-americano - o El Dorado, trata de "uma das personagens historiograficamente mais violentas e desconcertantes da colonização espanhola: Lope de Aguirre” com o intuito de averiguar a reelaboração do discurso hegemônico do passado. Os articulistas argumentam que o romance histórico "permite ampliar o espaço imaginativo e questionador acerca de uma das personagens mais controversas do período da colonização Latino-americana".

Seguem três artigos com foco centrado na literatura brasileira. Em A representação literária de Lampião em Rachel de Queiroz: nuances de autoritarismo, Maria Edileuza Costa e Irio José do Nascimento Germano Júnior analisam a construção da identidade na obra literária Lampião (2005), de Rachel de Queiroz. Segundo os articulistas, o enredo da peça expõe identidades fragmentadas e, nessa perspectiva, seria possível perceber "crenças, hábitos e ações nas quais o caráter e comportamentos dos cangaceiros tomam forma 'exclusa' da ótica social".

Em seu artigo Caio Fernando Abreu e as histórias de um novo tempo: epistolografia e literatura brasileira, Mara Lúcia Barbosa da Silva utiliza "como corpus de pesquisa o livro de cartas de Caio F., organizado por Moriconi (2002), correspondência do acervo do autor no Delfos/PUCRS e edições de O pasquim, entre outros materiais”. Em suas análises, a autora observa a importância da literatura para o escritor, chegando à conclusão de que "a escrita e o escrever eram vitais para Caio, o que se comprova pelo fato de que ele nunca parou de escrever, fosse a sua literatura, que se pode constatar pela extensão de sua obra, pelas suas cartas e outros tantos escritos como também pelos seus 'biscates culturais', que lhe permitiram sobreviver ao longo do tempo."

Finalizando a edição, em Manoel de Barros - A paisagem e a linguagem, Dóris Helena Soares da Silva Giacomolli e Antônio Carlos Mousquer apresentam uma leitura da obra do poeta e realçam, na obra do escritor mato-grossense, "o diálogo dos seus textos com as palavras, buscando conhecer alguns recursos utilizados pelo autor no seu fazer poético, no qual os objetos e seres rasteiros ao derredor 'animizam-se". O artigo conclui que a "paisagem fornece ao poeta um modelo para pensar a complexidade de uma realidade, e ao fazê-lo, [...] faz dela uma nova imagem, mágica, criada pelo trabalho de imaginação".

Agradecemos aos autores a disponibilização de seus textos e esperamos que os artigos desta edição de número 30 da Revista Literatura e Autoritarismo proporcionem reflexões profícuas aos leitores. 